\title{
SIGNOS DO CONSUMO, CALEIDOSCÓPICA
}

Clotilde Perez 1

Eneus Trindade 2

Esta primeira edição de 2011, que inaugura o terceiro ano da Signos do Consumo, apresenta a costumeira diversidade de abordagens das questões da Comunicação, da Cultura e do Consumo, materializada pelas diferentes áreas de formação e pesquisa dos autores e também pelas diferentes origens geográficas e institucionais. Uma vez mais garantimos a presença de autores internacionais e a multiplicidade regional brasileira. A revista conta com 6 artigos e 2 resenhas de livros, que a seguir serão apresentados.

O texto inaugural da edição intitulado "A Fantasia Enquanto Ritual e Apelo Publicitário: Uma Proposta de Análise Intertextual", de Suzana Silva e Rui Torres, ambos da Universidade Fernando Pessoa, na cidade do Porto em Portugal, trata a fantasia enquanto dimensão de evasão para onde o indivíduo se projeta, por meio da promessa idílica do consumo feita pela publicidade. Os autores analisam diversos anúncios que demonstram de que maneira a intertextualidade surge como estratégia privilegiada que convoca o leitor ao texto publicitário, remetendo-o para um universo de referências e textos inscritos na sua memória e na sua cultura, estimulando a imaginação e o despertar da fantasia. A intertextualidade na publicidade é diversa e se apresenta em diferentes níveis de complexidade, desde a presença do gênero literário, obras e estruturas narrativas que se inscrevem nos conhecimentos do leitor, expressões verbais e elementos iconográficos como gênios e lâmpadas mágicas ou ainda figuras gigantescas que remetem para a magia dos objetos e para a sua capacidade de transportarem o indivíduo a um universo paralelo e prazeroso. Texto primoroso e profundidade de análise.

"O Jornalismo na Economia de Mercado: Estudo da Revista Veja” é o artigo apresentado por Maria Inez Mateus Dota e Denise Fernandes Britto, ambas da Unesp de Bauru. As autoras trazem a discussão acerca da complexidade das relações econômicas, sociais, culturais e históricas que somadas influenciam o cotidiano do processo jornalístico, desde o despertar para o interesse de determinada pauta até a edição final da notícia. A partir dessa rotina, buscaram destacar como a economia de mercado está presente na materialidade discursiva da revista Veja. Para tanto, foram analisados os aspectos verbal e não-verbal de uma reportagem de Saúde publicada na revista, verificando o consumo como uma das finalidades jornalísticas da atualidade.

O terceiro artigo desta edição é de autoria de Sergio Roberto Trein, da Unisinos - RS. Intitulado "O Paradoxo dos Gimmicks na política: Por que humanizar quem já é humano?” e tem como objetivo 
central compreender o uso de gimmicks na comunicação política. O autor inicia sua reflexão a partir da constatação de que na publicidade, os gimmicks servem para humanizar os produtos e, desta forma, criar um vínculo emocional com os consumidores. Mas questiona. Por que, no caso da política, é preciso humanizar quem já é humano? Para tentar explicar esta questão é apresentada uma reflexão teórica sobre a desconfiança dos indivíduos nas instituições democráticas, para na sequência, analisar os gimmicks de três políticos específicos. Uma das conclusões é que diante do cenário de tamanha desconfiança nos políticos brasileiros e da crise da representação política, em função de uma indiferença quanto ao papel das instituições democráticas, fica evidente que de fato, o político se desumanizou. Nesse sentido, a utilização dos gimmicks aporta a humanização "perdida" e ajudam a quebrar a monotonia visual da linguagem política tradicional nas campanhas eleitorais funcionando como elemento "rehumanizador" de quem já é humano, mas que vem perdendo esta condição politicamente.

A publicidade para causas sociais é a apresenta por Monica Machado, Fernanda Martinelli e Marta Pinheiro, da ECO-UFRJ, por meio do texto "Publicidade para Causas Sociais: Apontamentos sobre a experiência do Laboratório Universitário de Publicidade Aplicada (LUPA)". O texto trata da comunicação publicitária diante das transformações sociais, culturais e tecnológicas contemporâneas, reforçando o papel da Universidade Pública no ensino, extensão e na pesquisa de temas sobre o consumo, a publicidade e a responsabilidade social. O relato sobre o Laboratório Universitário de Publicidade Aplicada nos leva a compreender a importância da agência experimental no processo de formação acadêmica, aliando a reflexão teórica com o fazer coletivo. Fernanda Rodrigues Pucci, da Universidade Tuiuti e da FAPAR - Paraná apresenta o artigo "Ver, Ler, Tocar e Participar do Anúncio Impresso da Cerveja Sol”. O objetivo da autora foi o de apresentar a análise teórica e técnica, de um dos anúncios de lançamento da cerveja SOL no Brasil. Para tanto, resgatou conceitos acerca da imagem icônica e da retórica publicitárias com foco no anúncio impresso. Por meio da análise da campanha impressa da cerveja Sol e da reflexão teórica a partir de Peirce, Eco e Barthes, foi possível conhecer como ocorre a formação de sentido nas mensagens publicitárias que usam da interação com o receptor como sua principal estratégica. A autora conclui suas reflexões revelando a potência da interação no processo de persuasão publicitária.

O penúltimo artigo desta edição é “TV, Espectadores e transmidiação reativa em Martín-Barbero", de Alexandre Honório da Silva, da Universidade Federal do Rio Grande do Norte. O artigo propõe uma interpretação do receptor/espectador nos processos de comunicação tendo como foco norteador as teorias e as proposições do pesquisador espanhol Jesús Martín-Barbero. Adicionalmente o autor 
procura introduzir o conceito cartográfico proposto por Martín-Barbero como um modelo de interpretação possível do lugar contemporâneo ocupado pelo receptor nas demandas comunicacionais e na mediação dos processos culturais.

Para encerrar este número da Signos do Consumo, temos o texto intitulado "A práxis enunciativa na publicidade contemporânea: a tensão entre permanência e fugacidade nos rituais de compra, uso e posse", de Eneus Trindade, Universidade de São Paulo, Pedro Hellin, da Universidad de Murcia, Espanha, Clotilde Perez da Universidade de São Paulo e PUC SP, Paulo Lencastre, Universidade Católica Portuguesa e Leandro Batista também da Universidade de São Paulo. O texto materializa uma longa e ampla parceria entre os pesquisadores e suas instituições, que integra as diversas possibilidades de relacionamentos e parcerias na investigação, na docência e na extensão universitária. O presente artigo parte da análise dos diferentes modos de presença do visível em nosso meio, culminando com o entendimento de que a publicidade se configura como uma manifestação privilegiada da sociedade contemporânea, baseada na sinestesia, na polifonia e na visualização dos conceitos de singularidade e exclusividade. Este feito está evidenciado pelo deslocamento da materialidade do produto a favor da desmaterialização simbólica, erodindo o concreto com a intenção de criar vínculos de sentido a partir da subjetividade para, com isso, estabelecer cumplicidade e identificação. A publicidade é presença efetiva, envolvente e intencionalmente acessível, criada como uma síntese da tensão entre a promessa de permanência e a fugacidade implacável característica do pragmatismo e o efêmero da oferta e a demanda contemporâneas. Neste contexto foram selecionados anúncios publicitários publicados nos últimos três anos nas principais revistas brasileiras, nas categorias de moda, tecnologia e alimentos, com mais de quinhentos exemplos. Por meio de uma metodologia teórico-empírica, os anúncios foram analisados semioticamente e comparados com os mecanismos de transferência de sentido a partir das reflexões de McCracken (2003), o que permitiu a compreensão de como se realizam os processos de significação das marcas a partir dos rituais de compra, uso e posse evidenciados nos anúncios. Adicionalmente, foram analisados os resultados sobre tendências obtidos na pesquisa Observatório de Tendências do Instituto Ipsos 2010 (Brasil) e do Trend Report 2009/2010 do Instituto Trend Watching (Holanda). Há que se destacar que nas expressões plásticas e textuais publicitárias encontramos reflexos da sociedade em suas diferentes manifestações, seus valores e suas pautas de conduta, além de importantes índices para projetar previsões, o que reforça a afirmação de que a publicidade é uma evidência privilegiada do mundo em que vivemos.

Além dos artigos que compõe a Signos, contamos também com duas resenhas. A primeira de autoria de Bruno Pompeu Marques Filho, doutorando da Universidade de São Paulo e professor do IED - 
Instituto Europeo de Design, criativamente intitulada "Inspirações Moçambicanas", é baseada no livro de Mia Couto "E se Obama fosse africano? e outras intervenções", de 2011. O texto trata das inter-relações entre a sabedoria popular e a reflexão teórico-filosófica profunda, passando por questões contemporâneas como as identidades plurais e o consumo. Para finalizar o autor introduz uma citação direta de Mia Couto "poesia e ciência são entidades que não se podem confundir, mas podem e devem deitar-se na mesma cama” (2011, p. 60). Saber, com sabor e poesia.

A segunda resenha construída por Eneus Trindade, da Universidade de São Paulo e co-editor da Signos do Consumo, apresenta a síntese das reflexões e proposições do livro Mascotes, semiótica da vida imaginária, de Clotilde Perez, também co-editora da revista, por meio do título, não menos criativo "O Mundo Divertido das Mascotes Levado a Sério". Traz o detalhamento da estruturação da obra, passando pelas questões conceituais sobre a personagem em diversas regionalidades científicas, a discussão sobre o termo "mascotes" até a construção de identidade e o fetiche contemporâneo, além do modelo de criação e análise das mascotes e finaliza com uma proposta de taxionomia de personagens e mascotes. $\mathrm{O}$ autor afetivamente faz o convite para o "contato imediato" com a fantástica "Semiótica da vida imaginária" das mascotes. Nada como poder contar com um amigo-pesquisador e pesquisador-amigo.

Aos amigos-leitores, ótima viagem!

Os Organizadores.

1-Professora Livre-Docente em Ciências da Comunicação do Departamento de Relações Públicas, Propaganda e Turismo da ECA/USP. Possui Pós-doutorado em Comunicação pela Universidade de Múrcia-Espanha. Doutora em Comunicação e Semiótica pela PUC-SP, Mestre em Administração pela PUC-SP. Docente do PPGCOM/ECA/USP na área de interfaces sociais da comunicação. Coordenadora dos Grupos de Estudos Semióticos em Comunicação, Cultura e Consumo $\mathrm{CNPq} / \mathrm{ECA} / \mathrm{USP}$.

2-Professor Doutor do Departamento de Relações Públicas, Propaganda e Turismo da ECA/USP. Possui Pós-doutorado em Antropologia Visual pela Universidade Aberta de Portugal. Doutor e Mestre em Ciências da Comunicação pela ECA/USP. Docente do PPGCOM/ECA/USP. Vicecoordenador do Grupo de Estudos Semióticos em Comunicação, Cultura e Consumo $\mathrm{CNPq} / \mathrm{ECA} / \mathrm{USP}$. 